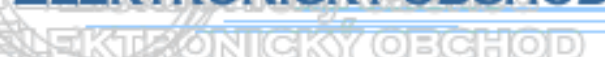

\title{
ANALÝZA TRHU S INFORMAČNO-KOMUNIKAČNÝMI TECHNOLÓGIAMI NA SLOVENSKU
}

\author{
Iveta Kremeňová, Martina Kováčiková*
}

\section{Úvod}

V predchádzajúcom čísle časopisu sme mali možnost' oboznámit' sa s celkovou analýzou vývoja trhu s informačno-komunikačnými technológiami vo svete a jeho štruktúrou. Teraz by sme nadviazali na predchádzajúci článok analýzou trhu $\mathrm{s}$ informačnokomunikačnými technológiami na slovenskom trhu a priblížime si trh rozvíjajúceho sa internetového obchodu.

\section{Informačno-komunikačné technológie}

Informačno-komunikačné technológie (ICT) zahíňajú produkty, ktoré uchovávajú, spracovávajú, manipulujú, chránia, vysielajú a prijímajú informácie elektronicky. „Termínom informačné technológie - rozumieme označenie všetkej techniky (hardvér - technické vybavenie systémov), ktorá sa zaoberá spracovaním informácií, t.j. ide o súbor prostriedkov a postupov na zber, prenos, uchovávanie, spracovávanie a prezentáciu informácií.“

Informačné technológie v spojení $\mathrm{s}$ integrovanými informačnými systémami predstavujú vzájomnú integráciu najrôznejších informačných systémov a systémov počítačovej podpory, či už pre technologickú prípravu výroby, organizáciu a riadenie výroby, plánovanie, skladovú evidenciu alebo používanie prostriedkov a metód umelej inteligencie. Jedná sa o technickú, organizačnú a telekomunikačnú techniku, jej príslušné programové vybavenie a organizačné usporiadanie jednotlivých zložiek.

ICT sú teda tiež zariadenia informačnej a výpočtovej techniky, zariadenia televíznej a audiovizuálnej techniky a $\mathrm{v}$ neposlednom rade telekomunikačnej techniky. Medzi ne patria servery, pracovné stanice $\mathrm{v}$ podnikoch ako aj osobné počítače vybavené modemom, $\mathrm{CD}$ alebo DVD mechanikou, klávesnicou a inými vstupnými a výstupnými zariadeniami. Tiež tam môžeme zaradit' aj televízne prijímače, satelitné prijímače, zariadenia mobilnej techniky a iné.

\section{Slovenský trh s informačnými a komunikačnými technológiami}

Slovenský trh informačných a komunikačných technológií pokračuje vo vysokej dynamike rastu. $\mathrm{V}$ tabul'ke č.1 sú uvedené výdavky na informačno-komunikačné produkty prostredníctvom jednotlivých zložiek slovenského ICT trhu.

Doc. Ing. Iveta Kremeňová, PhD., Ing. Martina Kováčiková, Katedra spojov, F-PEDAS, Žilinská univerzita tel.: 041/5133100, fax: 041/5655615

e-mail: Iveta.Kremenova@fpedas.utc.sk, Martina.Kovacikova@fpedas.utc.sk 
Tabul'ka č. 1. ICT trh v SR, v roku 2004 a prognóza pre rok 2005, v mil. Euro (zdroj: http://www.itnews.sk/buxus_dev/generate_page.php?page_id=2652)

\begin{tabular}{|c|c|c|c|c|}
\hline $\begin{array}{c}\text { Výdavky na informačno- } \\
\text { komunikačné produkty a } \\
\text { služby na Slovensku (mil. } \\
\text { Euro) }\end{array}$ & Predaj & $\begin{array}{c}\text { Percentuálne } \\
\text { vyjadrenie }\end{array}$ & $\begin{array}{c}\text { Prognóza } \\
\text { predaja }\end{array}$ & $\begin{array}{c}\text { Zmena } \\
\text { (\%) }\end{array}$ \\
\cline { 2 - 5 } & 2004 & 2004 & 2005 & $2005 / 2004$ \\
\hline Počítačový hardvér & 317 & 15,9 & 319 & 0,6 \\
\hline Kancelárska technika & 27 & 1,4 & 29 & 7,4 \\
\hline $\begin{array}{c}\text { Koncové komunikačné } \\
\text { zariadenia }\end{array}$ & 140 & 7 & 155 & 10,7 \\
\hline Dátové a siet'ové zariadenia & 232 & 11,6 & 243 & 4,7 \\
\hline Softvér & 135 & 6,8 & 150 & 11,1 \\
\hline IT služby & 197 & 9,9 & 224 & 13,7 \\
\hline Trh IT & $\mathbf{7 3 6}$ & $\mathbf{3 6 , 8}$ & $\mathbf{7 9 0}$ & $\mathbf{7 , 3}$ \\
\hline Služby operátorov & 950 & 47,5 & 998 & 5,1 \\
\hline Telekomunikačný trh celkovo & $\mathbf{1 2 3 5}$ & $\mathbf{6 1 , 8}$ & $\mathbf{1 3 2 0}$ & $\mathbf{6 , 9}$ \\
\hline \multirow{2}{*}{ ICT trh celkovo } & $\mathbf{1 9 9 8}$ & $\mathbf{1 0 0}$ & $\mathbf{2 1 0 9}$ & $\mathbf{5 , 6}$ \\
\cline { 2 - 5 } & & & & \\
\hline
\end{tabular}

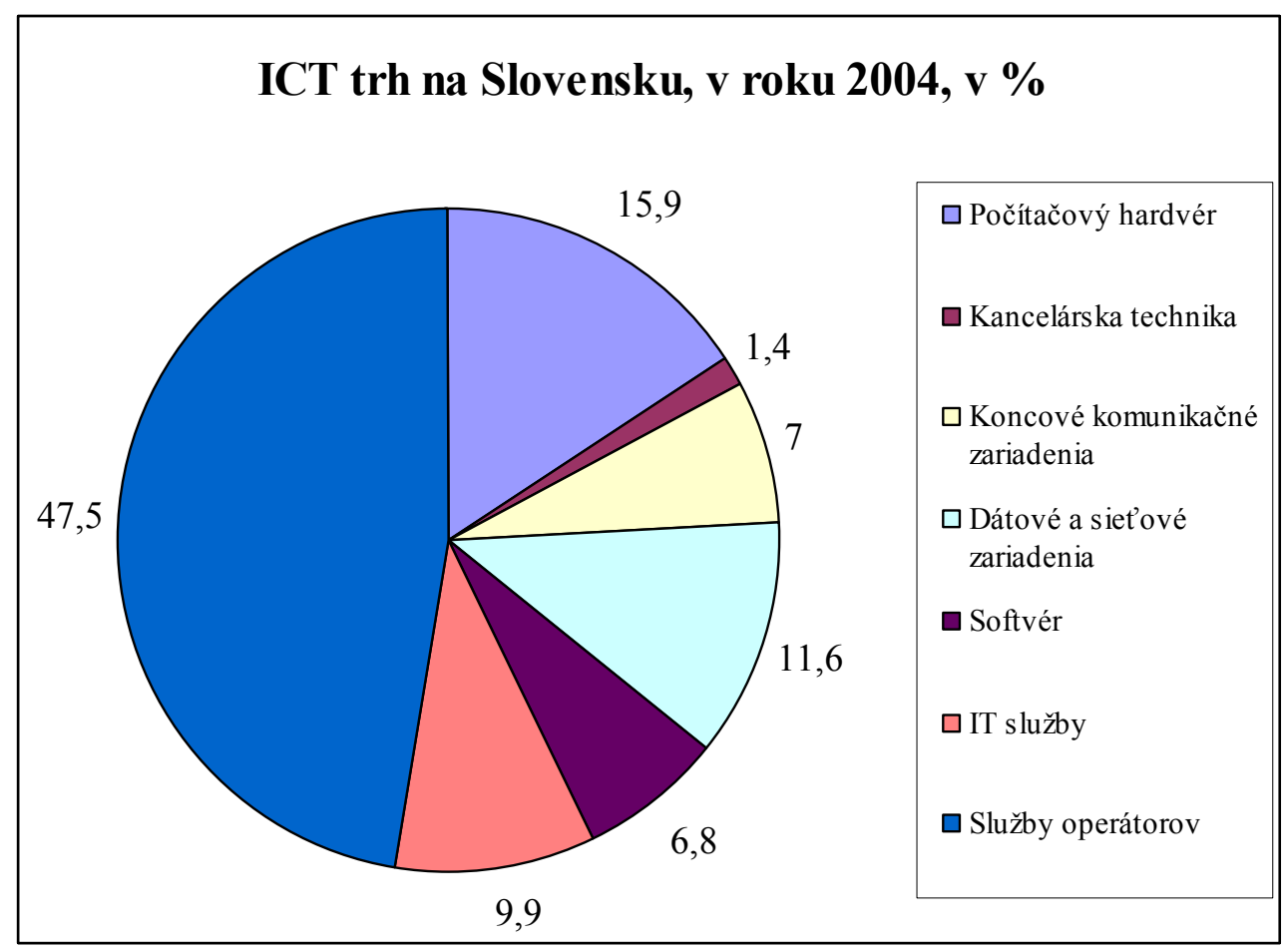

Graf č.1. Štruktúra ICT na Slovensku, v roku 2004, v \% (Zdroj: http://itnews.sk/buxus_dev/generate_page.php?page_id=2652) 
Z predchádzajúcej tabul'ky je zrejmé, že výdavky na ICT produkty a služby boli na Slovensku v roku 20041998 mil. Euro. Napriek tomu, že väčšinu tržieb získali operátori za svoje služby a dodávatelia hardvéru, na raste trhu sa viac podiel'ali softvér a príjmy za IT služby, ktorých predaj v uplynulom roku stúpol približne o 12 percent. Segmentová diferencia sa bude v nadchádzajúcich rokoch ešte viac zväčšovat'.

Z tabul'ky číslo 1 môžeme tiež určit' takmer $11 \%$ nárast koncových komunikačných zariadení. Tento nárast predstavuje v prevažnej miere predaj mobilných telefónov.

Podl'a EITO sa v roku 2004 na Slovensku na nákup IT produktov a služieb vynaložilo 140 eur (5 $600 \mathrm{Sk}$ ) na osobu, čo je hlboko pod priemerom Európskej únie (735 eur). Spomedzi nových členov patrí slovenský trh k menej rozvinutým.

Z priloženého grafického zobrazenia štruktúry ICT na Slovensku v roku 2004 je vidno, že najvyššie príjmy z predaja predstavujú služby operátorov, za ktorými nasleduje trh v oblasti IT.

V komerčnej sfére sa vo vel'kom nasadzujú aplikácie na riadenie podnikových zdrojov, systémy na podporu predaja (obchodu), budovania vzt’ahov so zákazníkmi či manažérskeho rozhodovania - business intelligence. $\mathrm{V}$ čoraz väčšej miere podniky pristupujú k nákupu tzv. „balíčkových riešení“ a outsourcingu. K rastu IT softwaru prispievajú aj rozsiahle projekty v štátnej správe, napríklad vytvorenie on-line katastra nehnutel'ností či informačného systému registra obyvatel'stva. Mnohé verejné zákazky súvisia so vstupom Slovenska do EÚ, s prispôsobením sa európskym štandardom.

Vd’aka miernemu ekonomickému oživeniu sa však čoraz viac otvárajú nové zákaznícke segmenty - menšie podniky a aj domácnosti, ktoré počítače doteraz využívali len vo vel'mi malej miere. Cena počítačov by pritom mala $\mathrm{v}$ budúcnosti vd’aka rastúcej konkurencii na úrovni maloobchodu klesat'.

Vysokú dynamiku rastu si zachováva aj slovenský telekomunikačný trh, na ktorom ide predovšetkým o súboj medzi Slovak Telecomom a alternatívnymi operátormi a medzi dvoma mobilnými operátormi. Z toho však môže koncový uživatel' iba t’ažit'. Uvidíme, aký vplyv bude mat' na trh s ICT tretí mobilný operátor.

\section{Internetový obchod}

Internetový obchod je nová sféra podnikania, ktorá síce zatial' priamo nepatrí do analyzovaného trhu s ICT, ale tieto dva pojmy spolu vel'mi súvisia a trh začne prenikat' čoraz viac do virtuálnej sféry.

Internetový obchod je taký druh obchodovania, kedy sa predávajúci a kupujúci stretávajú na internete. Predávajúci ponúka svoje výrobky a služby prostredníctvom internetu a kupujúci si ich tiež pomocou internetu objednáva. V nasledujúcej tabul'ke číslo 2 sú uvedené hodnoty internetového obchodovania v západnej Európe v roku 2005 a prognóza pre rok 2009. Údaje pre Slovensko v tom čase neboli k dispozícii. 
Tabul'ka č. 2. Hodnoty internetového obchodu v západnej Európe za rok 2005 a prognóza pre rok 2009 (zdroj: http://www.eito.com/download/EITO\%202006\%20-

\%20ICT\%20market\%20March\%202006.pdf)

\begin{tabular}{|c|c|c|c|c|}
\hline $\begin{array}{c}\text { Druh obchodu } \\
\text { / za roky }\end{array}$ & \multicolumn{2}{|c|}{2005} & \multicolumn{2}{|c|}{2009} \\
\hline $\begin{array}{c}\text { Business-to- } \\
\text { Consumer } \\
\text { (B2C) }\end{array}$ & 125,3 & 11,7 & 451,3 & 19,5 \\
\hline $\begin{array}{c}\text { Business-to- } \\
\text { Business } \\
\text { (B2B) }\end{array}$ & 943,1 & 88,3 & 1867,8 & 80,5 \\
\hline $\begin{array}{c}\text { Internetový } \\
\text { obchod } \\
\text { celkovo }\end{array}$ & 1068,4 & 100 & 2319,1 & 100 \\
\hline
\end{tabular}

Z tabul'ky č. 2 vyplýva, že väčšiu čast' internetového obchodu predstavuje B2B komunikácia (obchodovanie medzi spoločnost’ami), až 88,3\%, čo je 943,1 mld. Euro. Obchodovanie B2C (obchodovanie medzi podnikmi a koncovými užívatel'mi) predstavuje čiastku 125,3 mld. Euro. V roku 2009 by sa mali hodnoty mierne upravit', podiel B2C na celkovom internetovom obchode by mal vzrást' o necelých $8 \%$. Absolútna hodnota B2C internetového obchodu sa očakáva 451,3 mld. Euro a B2B internetového obchodu 1867,8 mld. Euro.

Sprievodným znakom rozvoja informačných technológií je nárast dostupných informácií, ktoré je vhodné využit' nielen na proces riadenia, ale najmä na samotnú analýzu údajov a zdokonal'ovanie riadiacej činnosti.

\section{Literatúra}

[1] http://www.eito.com/download/EITO\%202006\%20\%20ICT\%20market\%20March\%202006.pdf

[2] http://www.itnews.sk

[3] http://www.eito.org/download/eito\%202004\%20presentation\%Brussels\% 2019.02.04\%20Lamborghini.pdf

[4] MADLEŇÁK, R.: Elektronický obchod, EDIS ŽU Žilina, 2004, ISBN 80-8070-192-X

[5] MAJERČÁKOVÁ, M.: Technológia telekomunikácií, 1. vyd. - Žilina : Žilinská univerzita, 2003. - 166 s., AH 10,38, VH 10,86 : obr., tab. - ISBN 80-8070-159-8.

\section{Grantová podpora}

Článok vznikol pre podporu projektov VEGA - Vplyv výberu efektívnej stratégie na riadenie konkurencieschopnosti podniku $\mathrm{v}$ rámci liberalizácie poštových trhov a projektu MVTS Liberalizácia poštového trhu. 